\title{
SCHWANNOMA OF THE CLITORIS: A CASE REPORT
}

\author{
Yu-Suk Yu, MD, Do-Young Kwon, MD, Ji-Min Park, MD, Seok-Cheol Choi, MD, Sang-Young Ryu, MD \\ Department of Obstetrics and Gynecology, Korea Cancer Center Hospital, Korea Institute of Radiological and Medical Sciences, Seoul, Korea
}

Schwannomas arise from schwann cells in the peripheral nerve sheath, without involving the nerve fibers. Schwannomas are benign, slow-growing tumors that infrequently recur and rarely undergo malignant change. Also schwannomas of the female genitalia are considered extremely rare. We report a case of schwannoma of the clitoris. A 76-year-old woman without neurofibromatosis presented with a $2.0 \times 1.7 \mathrm{~cm}$, painless mass of the clitoris. Simple surgical excision of the mass was undertaken, and final pathology revealed schwannoma of the clitoris. No evidence of local recurrence was noted after 1 year of follow-up.

Keywords: Schwannoma; Clitoris

Schwannoma, neurinoma or neurilemmoma arise from schwann cells in the peripheral nerve sheath, without involving the nerve fibers.

Its most frequent sites are the extremities, posterior mediastinum, retroperitoneum, head and neck. On the other hand, schwannoma is a benign tumor which rarely affects the female genitalia $[1,2]$. Especially, despite the rich nerve supply of the clitoris, schwannomas of the clitoris are extremely rare [3-5]. We report a case of schwannoma of the clitoris.

\section{Case Report}

A 76-year-old postmenopausal Korean woman, who had four children, was referred to our hospital in 9 February 2010 for evaluation of vaginal spotting.

Physical examination revealed a $2.0 \times 1.7 \mathrm{~cm}$ sized, movable, nontender mass in the clitoris. But, she had not noticed the clitoral mass before; it was not painful.

Except for this lesion, her external genitalia was normal. She underwent hysterectomy 15 years before due to uterine prolapse. Her vagina was clear. There was no definite bleeding focus. Also, no abnormalities were detected on neurologic examination. She had no urinary or gastrointestinal problems. And there was no evidence of virilism and neurofibromatosis. About 7 years ago, she was diagnosed with myocardial infarction, and she has been taking heart medicines.
There was no family history of virilism or neurofibromatosis. And there was no family history of other hereditary disease. But, her brother died of lung cancer.

On 9 February 2010, simple surgical excision of the clitoral mass was performed under local anesthesia.

The specimen was a well demarcated, encapsulated and yellowish myxoid nodule measuring $2.0 \times 1.7 \times 1.5 \mathrm{~cm}$. There was no hemorrhage or necrosis (Fig. 1).

Microscopically, features of schwannoma were observed. The tumor was composed of many spindle cells with nuclear palisading arranged in whorls (Fig. 2).

There was no postoperative complication. And no evidence of local recurrence was noted after 1 year of follow-up.

Received: 2011. 6.10. Revised: 2011. 9.23. Accepted: 2011.10.14. Corresponding author: Seok-Cheol Choi, MD

Department of Obstetrics and Gynecology, Korea Cancer Center Hospital, Korea Institute of Radiological and Medical Sciences, 75 Nowon-gil, Nowon-gu, Seoul 139-706, Korea

Tel: +82-2-970-2157 Fax: +82-2-970-2157

E-mail: csc@kcch.re.kr

This is an Open Access article distributed under the terms of the Creative Commons Attribution Non-Commercial License (http://creativecommons.org/licenses/ by-nc/3.0/) which permits unrestricted non-commercial use, distribution, and reproduction in any medium, provided the original work is properly cited.

Copyright (๑) 2011. Korean Society of Obstetrics and Gynecology 


\title{
KOREAN JOURNAL OF OBSTETRICS \& GYNECOLOGY
}

\author{
KJOG Vol. 54, No. 12, 2011
}

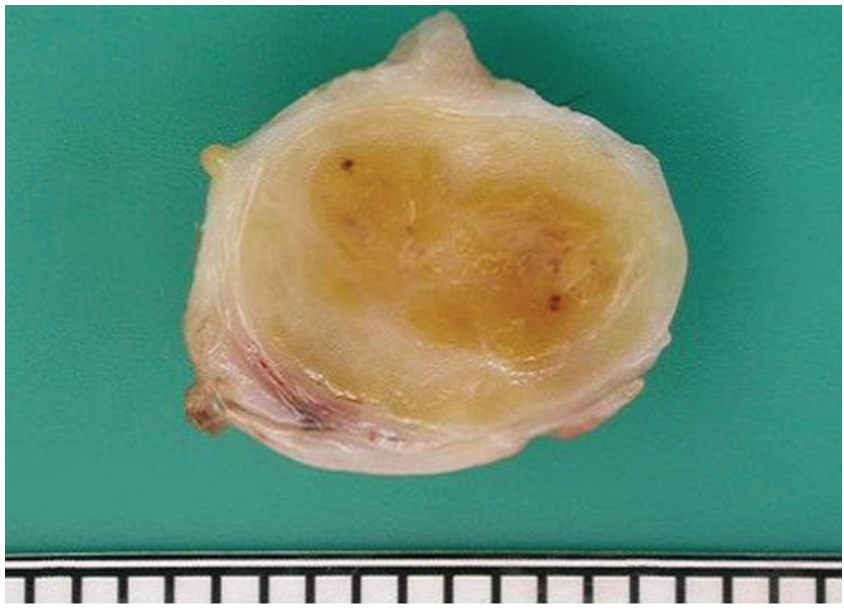

Fig. 1. Gross feature of specimen. Figure shows a $2.0 \times 1.7 \times 1.5 \mathrm{~cm}$ sized mass. Cut surface is well demarcated, encapsulated and yellowish myxoid.

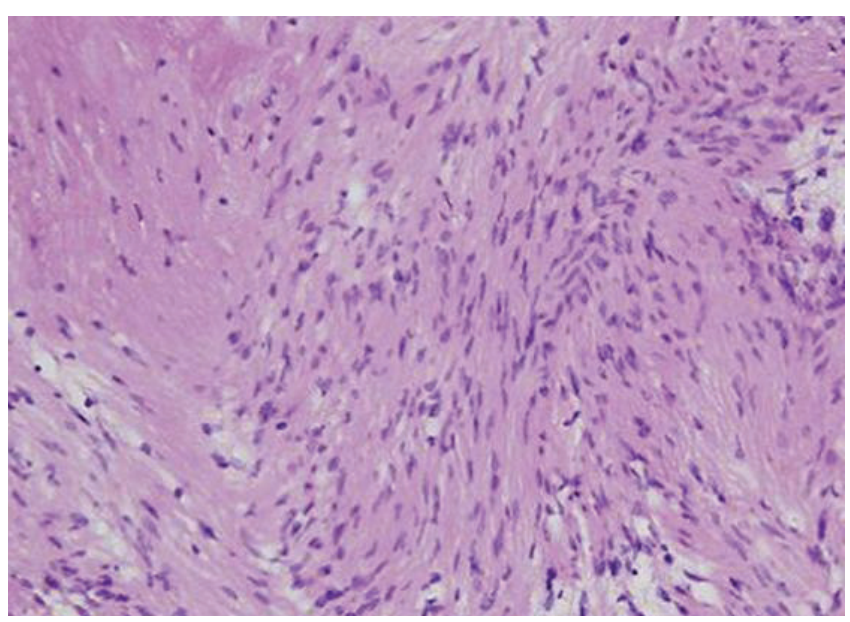

Fig. 2. Pathologic findings of specimen. Light microscopic appearance of tumor shows proliferation of many spindle cells with whorling pattern $(H \& E, \times 200)$.

\section{Discussion}

Schwannoma, also known as neurinoma, neurilemmoma, neurolemmoma [6] and perineural fibroblastoma [7] is a peripheral nerve sheath tumor characterised by proliferation of schwann cells [7-10].

Schwannomas rarely affect the female genitalia $[1,2]$. Especially, despite the rich nerve supply of the clitoris, schwannomas of the clitoris are extremely rare [3-5].

Schwannomas are benign, slow-growing tumors that infrequently recur and rarely undergo malignant change [11].

Histologically, the distinctive feature of schwannoma is the pattern of alternating Antoni $A$ and $B$ areas [7-10]. Antoni $A$ areas are composed of compacted spindle cells arranged in palisades or in an organoid arrangement (verocay bodies). Antoni B areas consist of tumor cells suspended in a loosely textured matrix with a more rounded cell morphology. Our case also showed that the tumor was composed of many spindle cells with nuclear palisading arranged in whorls.

Also, an immunohistochemical examination can be used in the diagnosis. In addition to the S-100 protein, positivity tumor cells express basal lamina components (such as laminin and type IV collagen), vimentins, and sometimes KP1 (CD68) and glial fibrillary acidic proteins [5].

The most common types of benign peripheral nerve sheath tumors are schwannoma and neurofibroma $[7,8]$. But microscopically, the presence of encapsulation, two types of Antoni areas, and diffusely strong immunostaining for S-100 protein distinguish schwannomas from neurofibromas [12]. And clinically, most of the clitoral neurofibromas occur in a background of neurofibromatosis, mostly neurofibromatosis type 1 [13], whereas none of the reported cases of clitoral schwannoma had neurofibromatosis. Neither in this case. In conclusion, despite its rarity, a schwannoma should be included in the differential diagnosis of a clitoral mass [14]. And simple surgical excision and follow-up considered as most adequate treatment [3].

\section{References}

1. Obeidat BR, Amarin ZO, Jallad MF. Vaginal schwannoma: a case report. J Reprod Med 2007;52:341-2.

2. Yamashita Y, Yamada T, Ueki K, Ueki M, Sugimoto O. A case of vulvar schwannoma. J Obstet Gynaecol Res 1996;22:31-4.

3. Cheng WC. Nerve tumour of the clitoris. Report of a case and commentary. J Obstet Gynaecol Br Commonw 1966;73:1016-7.

4. Huang HJ, Yamabe T, Tagawa H. A solitary neurilemmoma of the clitoris. Gynecol Oncol 1983;15:103-10.

5. Llaneza P, Fresno F, Ferrer J. Schwannoma of the clitoris. Acta Obstet Gynecol Scand 2002;81:471-2.

6. Kao GF, Laskin WB, Olsen TG. Solitary cutaneous plexiform neurilemmoma (schwannoma): a clinicopathologic, immunohistochemical, and ultrastructural study of 11 cases. Mod Pathol 1989;2:20-6.

7. Enzinger FM, Weiss SW. Benign tumors of peripheral nerves. In: Enzinger FM, editor. Soft tissue tumors. 3rd ed. St Louis: Mosby; 1995. p.821-63.

8. Scheithauer BW, Woodruff JM, Erlandson RA. Schwannoma. 


\section{KOREAN JOURNAL OF OBSTETRICS \& GYNECOLOGY}

Yu-Suk Yu, et al. Schwannoma of the clitoris: A case report

In: Scheithauer BW, Woodruff JM, Erlandson RA, editors. Tumors of the eripheral nervous system. Atlas of tumor pathology. 3rd series, Fascicle 24. Washington: Armed Forces Institute of Pathology; 1997. p.105-56,177-218.

9. Fletcher CD, Davies SE. Benign plexiform (multinodular) schwannoma: a rare tumour unassociated with neurofibromatosis. Histopathology 1986;10:971-80.

10. Fletcher CD. Peripheral nerve sheath tumors: a clinicopathologic update. In: Rosen PP, Fechner RE, editors. Pathology annual. Part 1. Norwalk: Appleton and Lange; 1990. p.51-74.

11. Woodruff JM, Selig AM, Crowley K, Allen PW. Schwannoma (neurilemoma) with malignant transformation. A rare, distinctive peripheral nerve tumor. Am J Surg Pathol 1994;18:882-95.

12. Weiss SW, Goldblum JR. Benign tumors of peripheral nerves. In: Weiss SW, Goldblum JR, editors. Enzinger and Weiss's soft tissue tumors. 4ed. St. Louis: Mosby, 2001. p.1111-1208.

13. Yüksel H, Odabaşi AR, Kafkas S, Onur E, Turgut M. Clitoromegaly in type 2 neurofibromatosis: a case report and review of the literature. Eur I Gynaecol Oncol 2003;24:447-51.

14. Chuang WY, Yeh CJ, Jung SM, Hsueh S. Plexiform schwannoma of the clitoris. APMIS 2007;115:889-90.

\section{음핵에서 발생한 신경집종 1예}

\section{한국원자력의학원 산부인과}

유유숙, 권도영, 박지민, 최석철, 유상영

신경집종은 말초신경초에 있는 슈반세포에서 발생하는 양성종양으로서 재발과 악성변화를 거의 하지 않고, 천천히 자라며, 여성의 생식 기관에서는 드물게 발생한다. 우리는 $2.0 \times 1.7 \mathrm{~cm}$ 음핵의 종괴를 단순 수술적 절제하였고, 종괴는 병리학적으로 신경집종 소견을 보였다. 1년 추적 관찰 후 국소 재발의 증거는 보이지 않았다. 이에 저자 등은 음핵에 드물게 발생하는 신경집종에 대해 보고하는 바이다.

중심단어: 신경집종, 음핵 